\title{
Determinants of banks' profitability and efficiency: Empirical evidence from a sample of Banking Systems
}

\author{
Mouna Rekik \\ Faculty of Economics and Management of Sfax, Tunisia \\ rekikmouna70@yahoo.fr \\ Maha Kalai \\ Faculty of Economics and Management of Sfax, Tunisia \\ helali.kalai.maha@gmail.com
}

\begin{abstract}
The aim of this study is to analyze the determinants of the bank profitability and efficiency in conventional banks. This study compares accounting-based and economic-based measures of efficiency and profitability of conventional banks in fourteen countries. Accounting variables help explain cost and profit efficiency, but cost efficiency has little impact on profitability and profit efficiency. In fact, the study of profitability is crucial in assessing the health of organizations. However, profitability of the banking sector is particularly important as the soundness of the sector is closely related to the soundness of the entire economy. In this paper, banks' profitability and its determinants in Tunisia as well as in 13 different countries were investigated. The determinants of bank profitability are analyzed with the data from 110 banks over the period 1999-2012 using the panel data method generalized method of moments. Our results suggest that researchers should probably focus more on profit efficiency than cost efficiency. Almost all banks are below the optimal size.
\end{abstract}

JEL Classification: G14, G21, G32

Keywords: Bank efficiency; Bank profitability; Economy of scale.

\section{INTRODUCTION}

Profitability has become one of the challenges faced by the commercial banks to strengthen their financial positions in order to meet the risks associated with openness and globalization. A profitable banking sector would withstand negative shocks better and contribute to the stability of the financial system. The profitability determinants are well observed and explored, as it is increasingly important to strengthen the foundations of the domestic financial system as a way to buildup flexibility for capital flow volatility. The commercial banks profitability is affected by 
Managerial (internal) and Environmental (external) factors. The managerial factors are affected by management decisions and goals to be achieved by the bank management; such as capital ratio, credit risk, productivity growth and size of the bank performance. The environmental factors are affected by external forces such as financial market structure, trade interdependence, economic growth, inflation, market interest rates and ownership structure.

The profitability of the banking sector is a subject that has received a lot of attention in recent years. There is now a large literature which has examined the role played by management of resources in determining bank profitability. It is generally agreed that better quality the management of resources is the main factor contributing to a bank performance, as evidenced by numerous studies that have focused on the U.S. banking system (DeYoung and Rice, 2004; Stiroh and Rumble, 2006; Bhuyan and Williams, 2006; Hirtle and Stiroh, 2007; Nicolae et al., 2015) and the banking systems in the western and developed countries (Ho and Tripe, 2002; Williams, 2003; Pasiouras and Kosmidou, 2007; Kosmidou et al., 2007; Kosmidou and Zopounidis, 2008; Athanasoglou et al., 2007; Albertazzi and Gambacorta, 2008). By contrast, fewer studies have studied this topic in developing economies.

Accounting-based research of bank performance generally used comprehensive information from financial statements to characterize the determinants of bank profitability, as calculated by return on assets (ROA) or return on equity (ROE). Studies, which examined an individual country (Kosmidou et al., 2007; and Ben Naceur and Goaied, 2008) or a geographical region (Kwan, 2003; and Bonin et al., 2005), have rather analyzed bank-specific factors of profitability (e.g., size, revenue growth, risk, and control of expenses). However, the research dealing with multiple countries (Hassan and Bashir, 2003; Valverde and Fernandez, 2007; Poghosyan, 2010; Ben Naceur and Omran, 2011; Muhammad et al., 2015) has included some external factors (e.g., inflation, concentration, and GDP growth) as well as several internal factors of profitability.

Economics-based studies have concentrated on efficiency, as measured by the distance away from some ideal frontiers calculated dependent to the lowest cost or highest profit bank in the sample. Diverse research studies have used nonparametric techniques, like data envelopment analysis (DEA) that applies no functional form on the cost or production function. The most popular approach in this trend focuses on the parametric estimation of cost, production, or profit functions. Throughout the parametric approaches, the Aigner et al. (1977) stochastic frontier approach (SFA) and the Berger (1993) distribution free approach (DFA) are the most prevalent and usually provide consistent efficiency rankings among banks. Although the SFA has been used more frequently than DFA, the later has the advantage of making several assumptions about the form of the error term and the distribution error terms adopted to estimate cost or profit efficiency.

In recent years, the bank performance literature is generally either accounting-based or economics-based. A number of articles, however, joined the aspects of both approaches such as, Berger and Mester (1997), Maudos et al. (2002), Hassan (2005), Fries and Taci (2005), Yildirim and Philippatos (2007) and Staikouras et al. (2008) whose analysis showed that the accountingbased correlates with economic efficiency measures.

Following this recent literature reviews, the purpose of this paper is to estimate cost and profit efficiencies for 110 banks in 14 countries. We estimate the Translog cost and profit functions to determine the economies of scale (ES) and the technical efficiency (TE) of each bank over the period 1999-2012. Moreover, we use the generalized method of moments (GMM) econometric model that enables us to investigate the relationship between bank profitability and some internal and external determinants.

Our study differs from the existing literature in many aspects. First of all, it uses a large number of conventional banks (110) and covers a wide range of countries (14 countries) over a longer time going from 1999 to 2012 (before, during and after the 2007 financial crisis). In addition, to estimate cost and profit frontier functions, specific variables have been introduced to each country (macroeconomic variables) to take into account the variation in the banking technologies 
which can be linked to macroeconomic conditions and the banking structure from one country to another. In addition, this study compares the scores of the cost and profit efficiencies per country, and attempts to identify the possible factors explaining the differences of cost and profit efficiencies observed for banks in some countries.

The remaining of this paper is organized as follows: First, we give a brief review of the literature examining the banks efficiency according to different approaches in the second section. The third section details our methodology. Our results are presents and discusses in the fourth section. Finally, we conclude and present the main recommendations of this study.

\section{LITERATURE REVIEW}

Research on the determinants of bank profitability has focused on both the returns on bank assets and equity, and net interest rate margins. It has traditionally explored the impact on bank performance of bank-specific factors, such as risk, market power, and regulatory costs. More recently, research has focused on the impact of macroeconomic factors on the banking performance.

Kumbirai and Webb (2010) investigated the performance of South Africa's commercial banking sector over the period 2005-2009. The study found that overall bank performance increased considerably in the first two years of the analysis. A significant change in trend is noticed at the onset of the global financial crisis in 2007, reaching its peak during 2008-2009. This resulted in falling profitability, low liquidity, and deteriorating credit quality in the South African Banking sector.

Sufian (2010) has analyzed the determinants of the bank profitability in Korea between 1994 and 2008, and the results of his study show that the banks presenting a lower credit risk have the tendency to record higher profitability levels. Regarding the impact of the macroeconomic and banking industry specific factors, the study shows that inflation has a significant pro-cyclical impact, the GDP has a counter-cyclical influence, and the banking sector concentration has a negative impact upon the profitability of the banks, as well.

Dietrich and Wanzenried (2010) investigated the main determinants of profitability for the Swiss banking market. Their empirical analysis, which was performed on a sample of 453 commercial banks in Switzerland, from 1999 to 2008, highlights the existence of some significant differences in the banks' profitability. The results of their study show that, on the one hand, the banks which are more capitalized are also more profitable, and on the other hand, regarding the crisis impact, the authors showed that the cost-income ratio had a significant impact on the return on assets only for the period before the crisis, while during the crisis a negative impact on the profitability was exerted by the loan loss provisions relative to total loans.

Alpera and Anbar (2011) examined the bank-specific and macroeconomic determinants of the banks' profitability in Turkey over the period 2002-2010. The results showed that asset size and non- interest income have a positive and significant effect on bank profitability. However, the size of credit portfolio and loans under follow-up has a negative and significant impact on this profitability. With regard to macroeconomic variables, only the real interest rate affects the performance of banks positively. These results suggest that banks can improve their profitability through increasing the bank size and non-interest income and decreasing the credit/asset ratio. In addition, a higher real interest rate can lead to higher bank profitability.

For Deger and Adem (2011), the banking profitability was measured by ROA and ROE as a function of bank-specific and macroeconomic determinants. Using a balanced panel dataset, the results showed that asset size and non-interest income have a positive and significant effect on banking profitability. However, the size of the credit portfolio and loans under follow-up has 
a negative and significant impact on this profitability. As for the macroeconomic variables, only the real interest rate affects the performance of banks positively.

Recently, Trujillo-Ponce (2013) have empirically analyzed the determining factors of banking profitability in Spain, between 1999-2009, and the differences between the performance of commercial and savings banks. The results show, in particular, that better capitalized banks have a higher level of return on assets. Regarding the exogenous variables, the study shows a positive relationship between the market concentration and the profitability of the Spanish banks, and also the importance of the economic cycle for the profitability of the banking sector. Regarding the performance of the commercial and savings banks, the study shows some important qualitative differences, in favor of the commercial ones.

Y1lmaz et al. (2013) analyzed profitability and its determinants for nine emerging countries including Turkey. The results reveal that operating expenses management, capitalization, credit risk, bank size and inflation are important determinants for both returns on asset and net-interest margin dependent variables.

Makkar and Singh (2013) carried out a comparative analysis of the financial performance of the Indian commercial banks considering a sample of 37 banks (22 public sector banks and 15 private sector banks) for the period from 2006-2007 to 2010-2011. Using the t-test, the results revealed a significant difference in the capital adequacy, asset quality and earning capacity of public and private sector banks in India. On the other hand, they found no significant difference in the management, liquidity position and sensitivity to market risk of the two different banking groups. Thus, it was concluded that, in average, there was no statistically significant difference in the financial performance of the public and private sector banks in India.

To illustrate that regulations and supervisory arrangements play an important role in shaping bank efficiency and productivity, we resorted to the results of Gaganis and Pasiouras (2013) that show that efficiency decreases as the number of the financial sectors supervised by the central bank increases. Additionally, banks operating in countries with greater unification of supervisory authorities are less profit efficient. Finally, the central bank independence has a negative impact on bank profit efficiency. Perhaps, Barth et al. (2013) contribute to this assessment by examining whether bank regulation, supervision and monitoring enhance or impede bank operating efficiency. Based on an un-balanced panel analysis of 4050 banks observations in 72 countries over the period 1999-2007, Barth et al. (2013) found that tighter restrictions on bank activities are negatively associated with bank efficiency, while greater capital regulation stringency is marginally and positively associated with bank efficiency. They also reveal that a strengthening of official supervisory power is positively associated with bank efficiency only in countries with independent supervisory authorities. Moreover, market-based banks monitoring in terms of more financial transparency is positively associated with bank efficiency.

Regarding the impact of financial freedom on bank efficiency, the results of Chortareas et al. (2013) suggest that the higher the degree of an economy's financial freedom, the higher the benefits for banks in terms of cost advantages and overall efficiency. Our results also show that the effects of financial freedom on bank efficiency tend to be clearer in countries with freer political systems in which governments formulate and implement sound policies and higher quality governance.

In addition, the latest accounting-based studies generally used panel techniques to examine banking profitability. For example, Kwan's (2003) made a comparison of the performance of banks in seven Asian countries for 1992-1999. Kosmidou et al.'s (2007), however, analyzed the profitability of the Greek banks operating abroad during 1995-2001, while Ben Naceur and Goaied's (2008) examined the profitability of 14 Tunisian banks over the 1980/2000 period. Athanasoglou et al.'s (2008) analyzed the bank-specific, industry-specific, and macroeconomic determinants of profit persistence in the Greek banks over the period 1985-2001. In general, the results of most of the above mentioned studies conclude that the measures of cost are generally 
negatively correlated with profits. Larger bank size, greater dependence upon loans for revenue, higher market concentration, greater GDP growth, and higher proportions of equity capital to assets have generally been correlated with greater profitability. Higher liquidity, greater provisions for loan losses, and more reliance on debt have been indicative of lower bank profits.

Other papers like those of Sealey and Lindley (1977) forwarded the intermediation framework for analyzing banking performance whereas Aigner et al.'s (1977) examined the cost efficiency of producing banking services in various developing countries using the stochastic frontier approach (SFA). Economics-based analysis of cost efficiency starts by calculating an ideal frontier based upon the cost of production and/or input usage of the highest practice or slightest cost firms in a sample. The use of a Translog cost function enables researchers to get away from actual data points to find an estimate of the minimum cost of production for any output level, or the minimum input usage for any level of total cost. This method was developed by Berger et al. (1993) to calculate profit efficiency in which inefficiency is measured according to the most profitable firms in the sample.

Other studies, like that of Bauer et al. (1998), Yildirim and Philippatos (2007) and Weill (2004, 2009) reached results using both of SFA and DFA and concluded that both approaches provide similar rankings of efficiency across banks. The DFA, however, presents a little percentage of efficiency scores across all the banks. Yildirim and Philippatos (2007) have used a truncation distribution and found average cost efficiencies of $71 \%$ using the DFA and $77 \%$ using the SFA for banks in 12 transition economies during the 1993-2000 period. Similarly, the profit efficiency figures were $51 \%$ for the DFA and $66 \%$ for the SFA. Regarding these differences in average efficiency levels, we opted for using the DFA method since it sets fewer assumptions about the distribution of the error terms.

Goddard et al. (2004) have attempted to identify determinants of banks' profitability in Denmark, France, Germany, Italy, Spain and the UK. The empirical results consider a positive relationship between capital-assets ratio and profitability. The relationship between the importance of off-balance-sheet business in a bank's portfolio and profitability is positive for the UK, but either neutral or negative elsewhere.

Kosmidou (2007) examined how a bank's specific characteristics and the overall banking environment affect the profitability of commercial domestic and foreign banks operating in the 15 EU countries over the period 1995-2001. The results indicate that profitability of both domestic and foreign banks is affected not only by a bank's specific characteristics but also by financial market structure and macroeconomic conditions. All the variables, with the exception of concentration in the case of domestic banks profits, are significant although their impact and relation with profits is not always the same for the two types of banks.

\section{METHODOLOGY}

In our study, we measured cost efficiency since it is able to estimate how close bank costs are to the best practice banks producing a similar bundle of outputs and operating under the same conditions. Such efficiency is obtained by calculating a stochastic cost frontier. If we obtain the cost frontier for a sample of banks, the total cost inefficiency of this bank shows the difference between the actual production costs for a given bank and the production costs estimated on the frontier. Inefficiency cost includes the technical and allocative inefficiencies. The allocative inefficiency is a result of the use of production factors in wrong proportions considering their market prices. The technical inefficiency is caused by an under use of production factors.

It is important to estimate the frontier of the production possibilities to get an efficiency cost measure. Some econometric techniques are applied to calculate efficiency such as the nonparametric and parametric approaches. 
The non-parametric approach does not need the specification of the functional form. However, this approach misses the random noise. This is investigated as a shortfall of the method because all the asymmetric deviations from the frontier are associated with inefficiency. However, the parametric approach applies a special functional form for the cost function, but considers the random noise in the parametric frontier specification.

The stochastic frontier approach includes a random error term which is split into two components, one is asymmetric and represents the inefficiency and the other is symmetric and captures the random error. In this study, we used the SFA and applied it to the banking industry in several studies. According to a long tradition in the banking literature, we used a Translog flexible functional form to estimate cost and profit functions. Banks consider the used labor, the physical capital and the financial capital as inputs which are supposed to produce deposits and investment services.

\subsection{Data, variables and samples}

To analyze the determinants of banking profitability and efficiency in the 14 countries, we used a panel data of 110 banks available in the bankscope database. The external variables affecting the bank performance (e.g., inflation and GDP) were collected from the International Monetary Fund (IMF). Furthermore, these banks belong to one country [Malaysia (MAL)] in the Southeast Asia region and 8 countries [Egypt (EGY), Yemen (YMN), Sudan (SDN), Iraq (IRQ), Syria (SYR), Tunisia (TUN), Jordan (JOR) and Lebanon (LBN)] in the MENA region (Middle East and North Africa) including 5 countries [United Arab Emirates (UAE), Bahrain (BHR), Kuwait (KWT), Saudi Arabia (SAU) and Qatar (QAT)] of the GCC (Gulf Cooperation Council).

Table 1.

Description of data sample: Average total assets in sample by country and year

\begin{tabular}{|c|c|c|c|c|c|c|c|c|c|c|c|c|c|c|c|}
\hline Country & SAU & BHR & EGY & IRQ & JOR & KWT & $\mathrm{LBN}$ & MAL & QAT & SDN & SYR & TUN & UAE & YMN & Total \\
\hline $\begin{array}{l}\text { Number } \\
\text { of banks }\end{array}$ & 9 & 12 & 13 & 1 & 12 & 5 & 9 & 12 & 6 & 9 & 4 & 4 & 11 & 3 & 110 \\
\hline GCC & yes & yes & no & no & no & yes & no & no & yes & no & no & no & yes & no & \\
\hline MENA & no & no & yes & yes & yes & yes & yes & no & yes & no & yes & yes & no & no & Average \\
\hline 1999 & 34.01 & 24.65 & 35.87 & 1.08 & 28.42 & 40.70 & 22.36 & 35.79 & 16.62 & 30.12 & 8.30 & 14.04 & 20.84 & 54.45 & 157.75 \\
\hline 2000 & 40.32 & 25.89 & 37.01 & 2.23 & 26.12 & 42.64 & 25.57 & 39.34 & 18.37 & 32.17 & 8.49 & 16.62 & 23.14 & 67.47 & 160.36 \\
\hline 2001 & 48.70 & 28.09 & 37.18 & 2.91 & 27.03 & 44.25 & 27.19 & 42.35 & 19.74 & 27.27 & 8.33 & 16.39 & 26.95 & 8.40 & 157.72 \\
\hline 2002 & 54.86 & 29.79 & 36.04 & 3.52 & 27.89 & 45.59 & 31.74 & 47.64 & 23.24 & 32.50 & 8.33 & 16.11 & 32.83 & 9.30 & 160.09 \\
\hline 2003 & 60.30 & 32.33 & 37.77 & 3.94 & 28.55 & 47.20 & 34.68 & 51.67 & 27.16 & 28.18 & 7.86 & 16.83 & 37.92 & 9.87 & 161.82 \\
\hline 2004 & 64.70 & 32.72 & 36.07 & 4.56 & 30.27 & 48.63 & 37.15 & 55.07 & 30.15 & 36.28 & 7.87 & 18.53 & 42.24 & 11.04 & 163.95 \\
\hline 2005 & 68.83 & 36.30 & 39.05 & 5.52 & 32.17 & 50.47 & 38.21 & 58.35 & 35.31 & 37.68 & 10.60 & 18.77 & 50.02 & 11.79 & 166.54 \\
\hline 2006 & 72.71 & 40.51 & 43.33 & 8.25 & 34.33 & 56.34 & 40.09 & 63.39 & 40.68 & 40.54 & 15.02 & 19.05 & 56.95 & 12.99 & 170.01 \\
\hline 2007 & 80.01 & 44.95 & 47.52 & 11.26 & 36.57 & 67.11 & 44.49 & 70.00 & 50.24 & 37.73 & 18.66 & 19.96 & 66.73 & 14.03 & 174.42 \\
\hline 2008 & 87.19 & 44.18 & 48.53 & 12.10 & 38.20 & 68.88 & 46.58 & 73.94 & 58.27 & 39.08 & 20.92 & 22.16 & 73.01 & 14.49 & 177.03 \\
\hline 2009 & 87.88 & 41.60 & 49.65 & 13.75 & 39.51 & 68.45 & 50.33 & 75.49 & 61.15 & 40.99 & 23.72 & 22.88 & 76.29 & 14.81 & 178.37 \\
\hline 2010 & 88.72 & 41.54 & 51.71 & 16.44 & 39.36 & 67.86 & 52.85 & 78.64 & 64.92 & 42.88 & 25.48 & 23.66 & 78.97 & 15.04 & 179.87 \\
\hline 2011 & 89.58 & 41.54 & 53.91 & 19.67 & 39.34 & 67.30 & 55.56 & 81.94 & 69.08 & 44.90 & 27.40 & 24.51 & 81.85 & 15.28 & 181.52 \\
\hline 2012 & 90.54 & 41.64 & 56.26 & 23.55 & 39.43 & 66.77 & 58.43 & 85.37 & 73.76 & 47.06 & 29.47 & 25.44 & 84.96 & 15.54 & 183.35 \\
\hline
\end{tabular}

Source: Authors' estimates from the data source. 
The period of analysis stretched over 1999-2012 during which an electronic data has become available for the majority of banks. The distribution of the banks sample of the 14 countries for the years 1999-2012 is shown in Table 1.

Many variables, used in previous studies to explain the banking profitability ratios are summarized in Table 2. The internal bank characteristics belong to the first category of explanatory variables. According to Kosmidou et al. (2007), the bank's size (SIZE) is represented by the logarithm of total bank assets. It is theoretically the most frequently used accounting variable in the banking studies and the literature proposes a positive relationship between profitability and SIZE.

The loan specialization ratio (LOANS) is the net loans divided by total assets. This ratio is not usually considered as a liquidity ratio, or as an asset utilization ratio. LOANS should positively influence profitability as long as a bank is not taking on an unacceptable level of risk because loans give the maximum return of any bank asset. The security specialization ratio (SECUR) is the ratio of other earning assets to total assets. Other earning assets involve all return-bearing assets other than loans meaning various types of securities. Staikouras et al. (2008) indicate that this ratio is positively associated with profitability. Yet, this relationship becomes negative if a bank does not invest much in securities at the expense of issuing loans. The deposit specialization ratio (DEPLIAB) is the specified total deposits divided by the total liabilities. The ratio of deposits to total assets has been analyzed in several studies and shows the importance of customer's deposits as a source of bank funds. Valverde and Fernandez (2007) justify that the variable could be either positively or negatively related to profitability because the deposits are both the lowest cost and the least stable source of funds.

Accounting ratios used to measure the internal banking efficiency are like the variables used in economics-based analysis in the following sub-section. The Inefficiency Ratio (INEFF), which represents the operating expenses divided by gross income, is possibly the extended single accounting measure of cost efficiency. Valverde and Fernandez (2007) showed that INEFF is negatively linked to banking profitability. This ratio can be divided into three parts defining the efficiency in using inputs.

Some studies used two measures of risk incorporate credit risk (CRISK) as measured by the loan-loss provisions to net loans ratio, and capital strength (CAPSTR), which is equity divided by total assets. Valverde and Fernandez (2007) suggested that the ratio of loan defaults to total loans had a negative relationship with banking profitability. Moreover, Kosmidou et al. (2007) proved the same relationship between profitability and the ratio of loan loss provisions to net interest income. Many studies like that of Berger and Mester (1997) have shown a positive relationship between profitability and capital strength. Similarly, Kosmidou et al. (2007) and Staikouras et al. (2008) state that some banks might be over-capitalized.

Table 2.

Definitions of variables

\section{Dependent variables}

TC: The total cost is defined as interest and cost out of interest in the efficiency cost function.

$\pi$ : Net operating profit. In the profit function, the total cost is replaced by total profit $(\pi)$ to avoid differences in taxation regimes between the countries in the sample.

ROA: Return on asset, which is defined as net income divided by total assets.

ROE: Return on equity, which is net income divided by average shareholder equity. 


\section{Independent variables}

Bank size (SIZE): The natural logarithm of the bank's total assets is used as a measure of a bank size. A larger size is expected to have a positive effect on bank profitability.

Loans specialization ratio (LOANS): the ratio of loans to total assets indicates which percentage of banking assets are represented by loans. The empirical studies indicate that an increase in the level of this indicator can state a deterioration of the soundness of loan portfolio, with a negative impact on profitability.

Security specialization (SECUR): Is the ratio of other interest bearing assets (non-loans) to total assets.

Deposit specialization (DEPLIAP): Is the ratio of total deposits to total liabilities.

Inefficiency (INEFF): Is the ratio of operating expenses to gross income.

Labor cost to come (LCI): Is the ratio of personnel expenses to gross income.

Credit risk (CRISK): Is the ratio of loan loss provisions to gross loans.

Capital strength (CAPSTR): Is the ratio of equity to total assets.

\section{External variables}

Country gross domestic product (CGDP): Is the year-to-year \% change in country gross domestic product deposits.

Inflation rate (INFL): Is defined as a sustained general rise in prices in an economy whereby high inflation rates are associated with higher costs as well as higher income.

The last group of explanatory variables measures the external or environmental factors generally outside the control of an individual bank. A change in gross domestic product (CGDP) represents the cyclical output. Previous studies, like that of Hryckiewicz and Kowalewski (2010), proposed that GDP growth has a positive impact on banking profitability over the business cycle. For this reason, our data are presented in nominal terms, whereas, inflation (INFL) is taken as a control variable as it might have a differential impact on outputs and inputs across banks and countries.

\subsection{Measuring efficiency}

Following a long tradition in the banking literature, we adopt a Translog flexible functional form to estimate banks' cost and profit functions. In Berger and Mester (1997), the intermediation approach is adopted so that assets on the bank balance sheet are treated as outputs, while liabilities and physical factors of production are treated as inputs.

Banks are assumed to use the inputs: $\mathrm{x}_{1}=$ labor, $\mathrm{x}_{2}=$ physical capital and $\mathrm{x}_{3}=$ deposits to produce the outputs: $\mathrm{y}_{1}=$ net loans, $\mathrm{y}_{2}=$ liquid assets and $\mathrm{y}_{3}=$ securities ratio. Deposits are the sum of all checking, savings, and time deposits at an institution measured in the Unite State dollar and its unit price $\left(\mathrm{p}_{3}\right)$ is defined as interest expense/deposits. Its share in the total cost $(C)$ is defined as $\mathrm{S}_{3}=$ interest expense/C, where $\mathrm{C}=$ interest expense + personal expenditures + depreciation and other operating expenses. The labor share of the total cost is $\mathrm{S}_{1}=$ personnel expenditures/ total cost, and its price $\left(\mathrm{p}_{1}\right)$ is the personnel's expenditures/total assets. This definition of price, as adopted by Maudos and al. (2002), can be used when data on the number of employees are not readily available. The physical capital is defined as expenditures on a plant and equipment measured by depreciation plus other capital expenses on the income statement. The capital share of the total cost is $\mathrm{S}_{2}=$ non-labor operating expenses/C and its price is estimated by $\mathrm{p}_{2}=$ nonlabor operating expenses/fixed assets.

Cost is measured by $\mathrm{C}=$ total cost $=$ operating expense + interest expense, estimated in $\log$ form by $\operatorname{Ln} \mathrm{C}$. Profit efficiency is calculated using the net operating profit $(\pi)$, which is net income minus provisions for loan losses, as presented by Maudos et al. (2002). Following Berger and Mester (1997), the dollar value of a financial equity capital for each bank is included as a quasifixed net put quantity (E) in the Translog unit cost and profit functions to help control risks. 
Table 3.

Descriptive statistics: economics-based variables (measured in $1000 \mathrm{~s}$ of U.S. dollars)

\begin{tabular}{lrcrc}
\hline \hline \multicolumn{1}{c}{ Variable } & Mean & Standard deviation & Minimum & Maximum \\
\hline $\mathrm{C}=$ Total Cost & 217.4 & 445.6 & 0.6 & 9918.8 \\
$\pi=$ Profit & 587.7 & 2452.1 & 0.02 & 64255.5 \\
$\mathrm{E}=$ Equity & 102205.4 & 158128.8 & 100.8 & 1414793.0 \\
$\mathrm{y}_{1}=$ Loans & 496038.4 & 888684.2 & 41.9 & 7600999.0 \\
$\mathrm{y}_{2}=$ Liquid assets & 272130.0 & 728626.7 & 109.8 & $1.84 \mathrm{e}^{+7}$ \\
$\mathrm{y}_{3}=$ Securities & 8440.1 & 13227.2 & 9.5 & 124081.2 \\
$\mathrm{~S}_{1}=$ Labor's share & 0.22 & 0.29 & $0.1 \mathrm{e}^{-3}$ & 0.99 \\
$\mathrm{~S}_{2}=$ Physical capital's share & 0.02 & 0.04 & 0 & 0.80 \\
$\mathrm{~S}_{3}=$ Interest's share & 0.76 & 0.29 & $0.9 \mathrm{e}^{-3}$ & 0.99 \\
$\mathrm{p}_{1}=$ Price of labor & 0.02 & 0.05 & $0.04 \mathrm{e}^{-4}$ & 0.84 \\
$\mathrm{p}_{2}=$ Price of physical capital & 0.01 & 0.02 & $0.01 \mathrm{e}^{-4}$ & 0.33 \\
$\mathrm{p}_{3}=$ Price of physical financial & 0.05 & 0.15 & $0.01 \mathrm{e}^{-4}$ & 1.85 \\
\hline \hline
\end{tabular}

Source: Authors' estimates from the data source.

The descriptive statistics for the economics-based variables for our data set of 527 banks are shown in Table 3. Prior to the estimation of cost or profit functions, all prices, costs, outputs, and inputs are scaled by the mean value of that variable in the sample. Using the information from the previous section about accounting based determinants of profitability, the variables INFL, GCC, SIZE, DEPLIAB, CGDP, RT (risk taking) and MS (market share) are included in the formulation of the cost and profit functions. Since countries in the data sample may have different regulatory regimes and quite different operating environments, Dietsch and Lozano-Vivas (2000) and Staikouras et al. (2008) stressed the importance of including country-specific environmental variables when estimating common multi-country cost and profit frontiers.

Following the procedure adopted by Fries and Taci (2005), we introduced two dummy variables (GCC and CHOC) where the first presents a country from the Gulf Cooperation Council and the second expresses the financial crisis after 2007. It takes zero from 1999 to 2006 and one afterwards.

To measure the efficiency cost, it is necessary to estimate the frontier of the production possibilities. Cost frontiers (and later profit frontiers) are annually estimated by adopting a Translog model similar to that of Dietch and Lozano-Vivas (2000), Maudus et al. (2002) and Yildirim and Philippatos (2007). In fact, we estimated two Translog functions. The first represented the cost function and the second showed the profit function. The Translog profit frontier was calculated in the same way as the cost frontier.

These two equations are characterized by the translogarithmic function form they take. This is a class of flexible functional forms that imposes few initial restrictive conditions on the technology underlying structure. For instance, this function explicitly allows multiple productions and lends itself easily to hypothesis tests on separability, homogeneity and unattached production. This specification may relate to the determination of the relationships between the different variables (complementarity or substitutability), on the one hand, and to the different elasticities in the estimation taking into account the individual specificities, on the other.

Using the linear homogeneity restrictions in input prices of the cost function, and assuming a production banking technology based on three inputs (deposits, labor and capital), and three outputs (loans, liquid assets and securities ratio) the cost function can be written as: 


$$
\begin{aligned}
& L n C=\alpha_{0}+\sum_{i=1}^{3} \alpha_{i} \operatorname{Lnp}_{i}+\sum_{n=1}^{3} \beta_{n} \operatorname{Lny}_{n}+\alpha_{t} t+\frac{1}{2} \sum_{i=1}^{3} \sum_{j=1}^{3} \delta_{i j} \operatorname{Lnp}_{i} \operatorname{Lnp}_{j}+\frac{1}{2} \sum_{n=1}^{3} \delta_{n m} \operatorname{Lny}_{n} . \operatorname{Lny}_{m}+\sum_{i=1}^{3} \sum_{n=1}^{3} \lambda_{i n} \operatorname{Lnp}_{i} \operatorname{Lny}_{n} \\
& +\gamma_{E} \operatorname{Ln} E+\frac{1}{2}(\operatorname{Ln} E)^{2}+\sum_{i=1}^{3} \varphi_{E i} \operatorname{LnE} \cdot \operatorname{Lnp}_{i}+\sum_{n=1}^{3} \gamma_{E n} \operatorname{LnE} \cdot \operatorname{Lny} y_{n}+\frac{1}{2} t^{2}+\sum_{i=1}^{3} \rho_{t i} t \cdot \operatorname{Lnp}_{i}+\sum_{n=1}^{3} \rho_{t n} t \cdot \operatorname{Ln} y_{n}+\gamma_{E t} t \cdot \operatorname{Ln} E \\
& +v_{1} I N F L+v_{2} G C C+v_{3} S I Z E+v_{4} D E P L I A B+v_{5} R T+v_{6} M S+v_{7} C G D P+v_{8} C H O C+u+v
\end{aligned}
$$

The regression parameters $\left(\alpha_{i}, \beta_{i}, \delta_{i j}, \delta_{n m}, \lambda_{i n}, \gamma_{i}, \varphi_{i}, \rho_{t i}, \rho_{t n}, v_{k}\right)$ are estimated using Nonlinear Least Square on the system of equations that includes the cost function plus the share equations $\left(\mathrm{S}_{1}, \mathrm{~S}_{2}\right.$ and $\left.\mathrm{S}_{3}\right)$ as follows:

$$
S_{i}=\alpha_{1}+\sum_{j=1}^{3} \delta_{1 j} \operatorname{Lnp}_{j}+\sum_{n=1}^{3} \lambda_{i n} \operatorname{Lny}_{n}+\varphi_{E i} \operatorname{LnE}+\rho_{t i} t+\varepsilon_{i} \quad \forall i=1,2,3
$$

The optimal level of demand of each input can be derived from the cost function by applying Shephard's lemma, which states that $\partial C / \partial p_{i}=X_{i}$ where $X_{i}$ is the optimal demand of the input $i$. The optimal cost factor is then defined by $C=\sum_{i=1}^{3} p_{i} \cdot X_{i}$ and the share of input $i$ in the total cost is written as $S_{i}=p_{i} \cdot X_{i} / C$ with $\sum_{i=1}^{3} S_{i}=1$. Since the share equations sum to one, the third share equation $\left(S_{3}\right)$ for Interest is omitted. Although the cost function can be estimated by itself, the addition of the two share equations into a system of three equations improves the precision of the parameter estimates. The terms $v, \varepsilon_{1}$ and $\varepsilon_{2}$ represent the stochastic error terms for each firm, while $u$ is a non negative term measuring potential inefficiency.

By differentiating the cost function with respect to the outputs $\mathrm{y}_{1}, \mathrm{y}_{2}$ and $\mathrm{y}_{3}$ (and assuming that outputs are additive), a measure of scale economies ( $S E)$ for any bank is:

$$
S E=\left(\sum_{n=1}^{3} S_{y_{n}}\right)^{-1}=\sum_{n=1}^{3} \beta_{n}+\sum_{n=1}^{3}\left(\operatorname{Lny}_{n} \cdot \sum_{m=1}^{3} \delta_{n m}\right)+\sum_{i=1}^{3}\left(\operatorname{Lnp}_{i} \cdot \sum_{n=1}^{3} \lambda_{i n}\right)+\sum_{n=1}^{3} \gamma_{E n} \operatorname{LnE}
$$

If $S E<1$, it means that bank is producing in the range of increasing returns to scale and an expansion of output would decrease per unit costs. However, $S E=1$ implies that the bank is at constant returns to scale, while $S E>1$ refers to diseconomies of scale if a bank is too big.

To obtain an optimal solution to the system of equations, some further restrictions are commonly imposed on the estimation of the Translog cost function. First, $\sum_{i=1}^{3} \alpha_{i}=1$ ensures that factor shares sum to one. Then, symmetry requires that $\delta_{i j}=\delta_{j i}$ and $\delta_{n m}=\delta_{m n}$ for all $i \neq j$ or $n \neq m$. Finally, a linear homogeneity in input prices imposes the following restrictions:

$$
\sum_{j=1}^{3} \delta_{i j}=\sum_{n=1}^{3} \delta_{n m}=\sum_{n=1}^{3} \lambda_{i n}=\sum_{i=1}^{3} \varphi_{E i}=0
$$

Moreover, the Translog function measures the relationship of substitutability or complementarity between inputs. They are measured by the price elasticity of demand inputs, defined by:

$$
\varepsilon_{i j}=\frac{\delta_{i j}+S_{i} \cdot S_{j}}{S_{i}} \quad \forall i, j=1,2,3 ; i \neq j \text { and } \varepsilon_{i i}=\frac{\delta_{i i}+S_{i}^{2}-S_{i}}{S_{i}} \quad \forall i=1,2,3
$$

$\varepsilon_{i j}<0$ means that $x_{i}$ and $x_{j}$ are complementary. Production technology is such that when price increases, the quantity applied $x_{j}$ decreases and vice versa.

$\varepsilon_{i j}>0$ means that $x_{i}$ and $x_{j}$ are substitutable. When $i$ input price increases, the quantity applied $x_{j}$ increases and vice versa. 
The error term $(\varepsilon)$ is decomposed into two components ( $v$ and $u)$. The first one $(v)$ is a twosided term representing the statistical noise that accounts for uncontrollable factors. This term is assumed to follow a symmetric normal distribution $v \rightarrow N\left(0, \sigma_{v}^{2}\right)$. The second one $(u)$ is a non-negative one-sided term which presents a cost inefficiency. Following Aigner et al. (1977), we assume that $u_{i t}$ are identically and independently distributed half normal random variables $u \rightarrow\left|N\left(0, \sigma_{u}^{2}\right)\right|$

The estimation of cost and of profit inefficiency requires the estimation of their frontier functions. The frontier can be estimated using either the maximum likelihood method or the moment method. We use the moment method because we estimate the whole system i.e. the cost frontier, the cost shares, and the demand function. The idea consists in calculating of the second and the third moments of the residuals of the cost functions. If we denote by $\mu_{2}$ and $\mu_{3}$ the second and the third central moments of these residuals, we can write:

$$
\mu_{2}=\frac{1}{N T} \sum_{i=1}^{N} \sum_{t=1}^{T}\left(\varepsilon_{i t}-\bar{\varepsilon}_{i}\right)^{2} \text { and } \mu_{3}=\frac{1}{N T} \sum_{i=1}^{N} \sum_{t=1}^{T}\left(\varepsilon_{i t}-\bar{\varepsilon}_{i}\right)^{3}
$$

Which corresponds to the following moment equation of Schmidt and Lovell (1979) and Greene (1997):

$$
\mu_{2}=\frac{\pi-2}{\pi} \sigma_{u}^{2}+\sigma_{v}^{2} \text { and } \mu_{3}=\sqrt{\frac{2}{\pi}}\left(\frac{4}{\pi}-1\right) \sigma_{u}^{3}
$$

To solve for the variance components, we have:

$$
\sigma_{u}^{2}=\left(\mu_{3} / \sqrt{\frac{2}{\pi}}\left(\frac{4}{\pi}-1\right)\right)^{\frac{2}{3}} \text { and } \sigma_{v}^{2}=\mu_{2}-\frac{\pi-2}{\pi} \sigma_{u}^{2}
$$

According to Jondrow et al. (1982), a cost inefficiency is estimated by the mean of the conditional distribution of $u_{i t}$ given $\varepsilon_{i t}$, using the following expression:

$$
E\left(u_{i t} \mid \varepsilon_{i t}\right)=\left(\frac{\sigma_{u} \sigma_{v}}{\sigma}\right)\left[\left(\phi\left(\frac{\varepsilon_{i t} \lambda}{\sigma}\right) / \Phi\left(\frac{\varepsilon_{i t} \lambda}{\sigma}\right)\right)+\frac{\varepsilon_{i t} \lambda}{\sigma}\right]
$$

where $\sigma^{2}=\sigma_{u}^{2}+\sigma_{v}^{2}, \lambda=\sigma_{u} / \sigma_{v}$ and $\phi\left(\frac{\varepsilon_{i t} \lambda}{\sigma}\right)$ and $\Phi\left(\frac{\varepsilon_{i t} \lambda}{\sigma}\right)$ are the standard normal probability density and cumulative distribution functions, respectively. However, in most situations, we are rather interested in the efficiency of $i$-th firm, $T E_{i}=\exp \left(-\hat{u}_{i}\right)$. However, Battese and Coelli (1988) used $P\left(u_{i} \mid y_{i}\right)$ to derive the alternative predictor:

$$
T \hat{E}_{i} \equiv E\left\{\exp \left(-u_{t}\right) \mid \varepsilon_{i}\right\}=\left[\Phi\left(\frac{u_{i}^{*}}{\sigma_{*}}-\sigma_{*}\right) / \Phi\left(\frac{u_{i}^{*}}{\sigma_{*}}\right)\right] \cdot \exp \left\{\frac{\sigma_{*}^{2}}{2}-u_{i}^{*}\right\}
$$

where $\sigma_{*}^{2}=\sigma_{u}^{2} \cdot \sigma_{v}^{2} / \sigma^{2}$. 


\section{EMPIRICAL ANALYSIS}

\subsection{Accounting profitability determinants}

Several studies like that of Kosmidou et al. (2007) and Van Horen (2007) suggested that return on assets (ROA) is the best measure of profitability over time since assets have a direct impact on both income and expenses. Nevertheless, the ROE can be a critical measure of profit in many cases. Our sample is an unbalanced panel and the models illustrating ROA and ROE are estimated using a generalized least square panel estimator because the number of years of the data varies by bank.

The basic framework for the panel models is:

$$
Y_{i t}=\alpha_{i}+\beta X_{i t}+\varepsilon_{i t}
$$

where $Y_{i t}$ is the dependent variable (either ROA or ROE), $\alpha_{i}$ is the firm specific intercept in fixed effect models and common intercept with random variation across banks in the random effects model, $\beta$ is a vector of the regression coefficients, $X_{i t}$ is a vector of the explanatory variables described in table 2 , and $\varepsilon_{i t}$ is the disturbance term which is supposed to be normally distributed with a mean of zero. However, several internal and external variables are highly correlated; where only a subset of independent variables $(k)$ is significant in determining the best model for each profitability ratio.

Table 4.

Fixed-effects panel regressions for the determinants of profitability ratios

\begin{tabular}{lcc}
\hline \multicolumn{1}{c}{ Independent variable } & ROA & ROE \\
\hline LOANS & $-0.013^{* * *}$ & $-0.212^{* * *}$ \\
& $(-9.32)$ & $(-6.53)$ \\
INEFF & $-0.033^{* * *}$ & $-0.322^{* *}$ \\
& $(-4.64)$ & $(-2.24)$ \\
CAPSTR & $0.036^{* * *}$ & $-2.234^{* * *}$ \\
& $(3.12)$ & $(-9.68)$ \\
CRISK & -0.006 & $0.204^{*}$ \\
& $(-1.04)$ & $(1.86)$ \\
INFL & $-0.5 \mathrm{e}^{-3}$ & $-0.5 \mathrm{e}^{-4}$ \\
& $(-1.30)$ & $(-0.01)$ \\
CHOC & $0.011^{* * *}$ & 0.060 \\
& $(3.59)$ & $(0.33)$ \\
Constant & $0.179^{* * *}$ & $3.098^{* * *}$ \\
& $(10.52)$ & $(8.11)$ \\
\hline Hausman test & $39.16^{* * *}$ & $41.53^{* * *}$ \\
Statistic significance & $(0.00)$ & $(0.00)$ \\
Wald test for GroupWise heteroscedasticity & $1.0 \mathrm{e}^{+6^{* * *}}$ & $1.2 \mathrm{e}^{+7^{* * *}}$ \\
Statistic significance & $(0.00)$ & $(0.00)$ \\
F-statistic & $25.85^{* * *}$ & $19.94^{* * *}$ \\
Statistic significance & $(0.00)$ & $(0.00)$ \\
\hline \hline
\end{tabular}

Note: t-statistics are in parenthesis below each coefficient. ${ }^{* * *},{ }^{* *}$ and ${ }^{*}$ show significance at $10 \%, 5 \%$ and $1 \%$, respectively.

Source: Authors' estimates from the data source. 
The highest fixed effect models for the ROA and the ROE are shown in table 4, where each includes four independent variables that are significant at 5\% level. The models present variations in ROA and ROE across banks rather than through the approximate F-statistic values of 25.85 and 19.94. In several studies, profitability decreases with the loan specialization ratio (LOANS) because a loan gives higher returns than other assets. The inefficiency ratio (INEFF) is significantly and negatively related to the ROA and the ROE considering that higher costs decrease profitability. The capital strength (CAPSTR) increases the ROA as argued in some studies. However, greater capitalization decreases risks and reduces earnings per share, that is why the ROE decreases. For this reason, our annual data are in nominal terms and inflation (INFL) acts as a control variable. It is linked neither to the ROA nor to the ROE, that is why significant results can be obtained using a time trend or the GDP growth (CGDP) variable instead of INFL. However, the credit risk (CRISK) positively affects the ROE indicator. These results are similar to those of various researchers including Sinkey and Greenwalt (1991) and Ahmed et al. (1998). Therefore, banks can effectively deal with credit and other risks that may affect bank's profitability severely. Credit risk management is a crucial part of measuring the optimizing profitability of financial institutions. A bank can improve the overall credit system by tackling asymmetrical information flow, and giving guarantee of loan repayment.

It is interesting to note that when we examine the 2008 subprime crisis, the coefficient of the variable $\mathrm{CHOC}$ is positive and significant suggesting an impact on the performance of the conventional banking sector during economic crisis periods. This result is not expected. However, this can be interpreted as a supporting evidence for the idea that the positive impact of financial crisis on bank efficiency is higher among the MENA countries banks as these countries were less affected by the global financial crisis.

\subsection{Economic-based examination of cost and profit efficiency}

The Translog cost and alternative profit functions are annually estimated using the iterative seemingly unrelated regression equations (SURE) method of Zellner (1962). As shown in table 5, the estimated average scale economies using Eq. (3) are $S E$ (Cost) $=0.638$ and $S E$ (Profit) $=0.577$. Since $S E<1$, there are fairly substantial economies of scale which are not being exploited across most banks. Such results are consistent with the findings of other banking studies in emerging markets (Lee, 2002; Al-Muharrami et al., 2006; Turk-Ariss, 2008).

Table 5.

Average Efficiency and scale economies in \%

\begin{tabular}{|c|c|c|c|c|c|c|}
\hline \multirow{2}{*}{ Countries } & \multirow{2}{*}{ ROA } & \multirow{2}{*}{ ROE } & \multicolumn{2}{|c|}{ Cost } & \multicolumn{2}{|c|}{ Profit } \\
\hline & & & Efficiency & Scale Economies & Efficiency & Scale Economies \\
\hline Saudi Arabia & 4.6 & 54.1 & 87.3 & 64.9 & 97.4 & 61.0 \\
\hline Bahrain & 3.6 & 34.7 & 86.9 & 65.2 & 96.9 & 60.5 \\
\hline Egypt & 3.4 & 44.5 & 88.2 & 66.2 & 96.8 & 61.1 \\
\hline Iraq & 2.9 & 23.5 & 86.9 & 65.6 & 97.0 & 60.0 \\
\hline Jordan & 2.6 & 19.2 & 87.6 & 65.4 & 97.0 & 59.7 \\
\hline Kuwait & 2.7 & 17.5 & 87.4 & 64.7 & 97.1 & 58.8 \\
\hline Lebanon & 2.7 & 18.1 & 87.2 & 63.5 & 97.3 & 57.5 \\
\hline Malaysia & 2.5 & 16.7 & 88.5 & 63.3 & 97.4 & 57.4 \\
\hline Qatar & 2.0 & 15.9 & 88.1 & 62.2 & 97.2 & 56.4 \\
\hline
\end{tabular}




\begin{tabular}{|c|c|c|c|c|c|c|}
\hline \multirow{2}{*}{ Countries } & \multirow{2}{*}{ ROA } & \multirow{2}{*}{ ROE } & \multicolumn{2}{|c|}{ Cost } & \multicolumn{2}{|c|}{ Profit } \\
\hline & & & Efficiency & Scale Economies & Efficiency & Scale Economies \\
\hline Sudan & 2.4 & 32.0 & 87.7 & 61.9 & 97.2 & 55.5 \\
\hline Syria & 2.5 & 16.9 & 87.7 & 62.1 & 97.2 & 55.3 \\
\hline Tunisia & 2.1 & 15.9 & 87.6 & 62.2 & 97.1 & 54.9 \\
\hline United Arab Emirates & 2.5 & 17.7 & 87.2 & 63.0 & 97.0 & 55.1 \\
\hline Yemen & 3.3 & 21.2 & 87.2 & 62.9 & 96.8 & 54.3 \\
\hline Total average & 2.8 & 24.9 & 87.5 & 63.8 & 97.1 & 57.7 \\
\hline GCC average & 3.2 & 30.6 & 87.4 & 63.8 & 97.1 & 58.2 \\
\hline
\end{tabular}

Source: Authors' estimates from the data source.

From the above table 5, it is estimated that an average bank operates at about $87 \%$ cost efficiency for all the banks. The results for both cost and profit functions are similar. Generally, the cost efficiency measures are slightly higher than those of the profit efficiency.

On a country by country basis, the banks in Egypt, Malaysia and Qatar are the most cost efficient - operating at about $88 \%$ cost efficiency. The least cost efficient banks are in Bahrain and Iraq $(86.9 \%)$. It should be noted that our estimates of cost efficiency are in line with the values of $85 \%$ and $93 \%$ obtained by Turk-Ariss (2008) using SFA quartile cost frontiers for Lebanese banks over the period 1990-2000.

As far as the profit efficiency is concerned, the average bank achieves about $97 \%$ of the profit practice bank. Focusing on the country estimates of profit efficiency, banks in Saudi Arabia and Malaysia reach 97.4\% profit efficiency, while banks in Lebanon achieve 97.3\% profit efficiency. The least profit efficient countries are Yemen and Egypt (86.8\%), while the most striking difference between cost and profit efficiencies are for Egyptian banks which operate at about 88\% cost efficiency and only $86.8 \%$ profit efficiency.

Our estimates of profit efficiency are somewhat larger than for developing and transition countries as reported by Maudos et al. (2002) and Yildirim and Philippatos (2007). The MENA countries banks are nearly as cost efficient as the European ones, but the difference between cost and profit efficiencies is generally found in other regions. This means that the MENA countries banks have performed relatively well in terms of profitability and profit efficiency compared to banks in other countries.

Table 6.

Average price elasticity of demands inputs in $\%$

\begin{tabular}{|c|c|c|c|c|c|c|c|c|c|c|c|c|c|c|c|c|c|c|}
\hline \multirow{2}{*}{ Country } & \multicolumn{9}{|c|}{ Cost } & \multicolumn{9}{|c|}{ Profit } \\
\hline & $\varepsilon_{11}$ & $\varepsilon_{22}$ & $\varepsilon_{33}$ & $\varepsilon_{12}$ & $\varepsilon_{13}$ & $\varepsilon_{21}$ & $\varepsilon_{23}$ & $\varepsilon_{31}$ & $\varepsilon_{32}$ & $\varepsilon_{11}$ & $\varepsilon_{22}$ & $\varepsilon_{33}$ & $\varepsilon_{12}$ & $\varepsilon_{13}$ & $\varepsilon_{21}$ & $\varepsilon_{23}$ & $\varepsilon_{31}$ & $\varepsilon_{32}$ \\
\hline Saudi Arabia & -0.6 & 7.3 & 61.5 & -1.7 & 49.8 & -14.3 & 36.2 & 26.0 & 3.2 & 2.6 & 8.2 & 59.4 & -3.5 & 48.1 & -17.1 & 30.4 & 26.3 & 3.5 \\
\hline Bahrain & -2.1 & 5.1 & 65.0 & -1.6 & 50.7 & -14.4 & 40.8 & 27.8 & 3.5 & -0.2 & 5.8 & 63.3 & -2.7 & 47.4 & -17.1 & 38.8 & 27.4 & 3.9 \\
\hline Egypt & 0.7 & 15.8 & 64.1 & -1.3 & 52.7 & -11.9 & 38.0 & 26.1 & 3.4 & 5.1 & 17.8 & 61.2 & -2.2 & 52.0 & -16.7 & 32.7 & 25.0 & 3.8 \\
\hline Iraq & -0.9 & 13.8 & 68.2 & -1.6 & 55.6 & -14.5 & 44.9 & 29.3 & 2.4 & 5.4 & 16.8 & 67.8 & -2.2 & 51.1 & -21.9 & 40.2 & 27.5 & 2.5 \\
\hline Jordan & 6.3 & 13.6 & 65.1 & -2.0 & 56.0 & -16.7 & 39.9 & 21.0 & 2.4 & 12.6 & 16.2 & 62.3 & -2.8 & 53.1 & -27.3 & 38.7 & 21.3 & 3.1 \\
\hline Kuwait & 10.6 & 24.9 & 64.7 & -2.5 & 51.9 & -22.5 & 35.3 & 28.4 & 1.8 & 15.9 & 26.2 & 62.4 & -3.7 & 48.1 & -22.7 & 32.7 & 26.1 & 2.3 \\
\hline
\end{tabular}




\begin{tabular}{|c|c|c|c|c|c|c|c|c|c|c|c|c|c|c|c|c|c|c|}
\hline \multirow{2}{*}{ ountr } & \multicolumn{9}{|c|}{ Cost } & \multicolumn{9}{|c|}{ Profit } \\
\hline & $\varepsilon_{11}$ & $\varepsilon_{22}$ & $\varepsilon_{33}$ & $\varepsilon_{12}$ & $\varepsilon_{13}$ & $\varepsilon_{21}$ & $\varepsilon_{23}$ & $\varepsilon_{31}$ & $\varepsilon_{32}$ & $\varepsilon_{11}$ & $\varepsilon_{22}$ & $\varepsilon_{33}$ & $\varepsilon_{12}$ & $\varepsilon_{13}$ & $\varepsilon_{21}$ & $\varepsilon_{23}$ & $\varepsilon_{31}$ & $\varepsilon_{32}$ \\
\hline Lebanon & 11.8 & 22.5 & 67.4 & -4.4 & 48.4 & -15.9 & 37.2 & 26.3 & 1.3 & 12.0 & 23.7 & 65.0 & -7.2 & 44.9 & -18.3 & 34.5 & 26.5 & 1.6 \\
\hline Malaysia & 16.2 & 24.0 & 67.9 & -4.7 & 47.0 & -16.3 & 26.8 & 24.1 & 2.0 & 16.6 & 22.6 & 66.6 & -5.6 & 44.7 & -22.0 & 32.5 & 24.5 & 2.8 \\
\hline Qatar & 16.7 & 27.6 & 66.8 & -4.8 & 48.1 & -22.5 & 29.7 & 20.5 & 3.0 & 15.1 & 28.9 & 64.0 & -5.4 & 44.3 & -25.5 & 29.7 & 20.8 & 4.4 \\
\hline Sudan & 12.0 & 23.1 & 67.6 & -5.3 & 48.8 & -18.6 & 35.1 & 25.8 & 1.0 & 15.6 & 25.1 & 64.7 & -5.9 & 46.7 & -25.1 & 33.5 & 26.0 & 1.3 \\
\hline Syria & 1 & 20 & 71.5 & -3.3 & 52.0 & -19.2 & 7 & 28.2 & 1.1 & 9 & 19.2 & 68.9 & -5.5 & 44.9 & -25.5 & 27.9 & 27.9 & 1.4 \\
\hline Tunisia & 15.8 & 26.0 & 70.9 & -3.7 & 51.9 & -18.3 & 32.3 & 27.7 & 1.3 & 14.9 & 26.3 & 68.4 & -6.1 & 49.2 & -22.7 & 30.4 & 27.9 & 1.6 \\
\hline $\begin{array}{l}\text { Unitec } \\
\text { Emira }\end{array}$ & 11.7 & 14.9 & 68.4 & -4.1 & 48.6 & -14.6 & 30.6 & 27.7 & 2.0 & 15.5 & 16.2 & 67.5 & -6.2 & 46.5 & -23.4 & 34.6 & 28.1 & 1.9 \\
\hline Yemen & 10.6 & 10.6 & 70.8 & -5.4 & 49.0 & -14.7 & 33.5 & 26.5 & 1.6 & 15.2 & 11.8 & 69.3 & -8.5 & 48.7 & -22.1 & 38.1 & 26.8 & 1.8 \\
\hline veray & 8.5 & 17.8 & 67.1 & -3.3 & 50.7 & -16.7 & 35.2 & 26.1 & 2.2 & 11.4 & 18.9 & 65.1 & -4.8 & 47.8 & -22.0 & 33.9 & 25.9 & 2.5 \\
\hline
\end{tabular}

Source: Authors' estimates from the data source.

Table 6 shows the average price elasticity of demand inputs between the different prices. The demand price elasticity shows the relationship between price and required quantity and provides a precise calculation of the effect of a change in price on the demanded quantity. The negative sign in cost average $\left(\varepsilon_{12}=-3.3\right.$ and $\left.\varepsilon_{21}=-16.7\right)$ indicates that $\mathrm{P}_{1}$ (price) and $\mathrm{P}_{2}$ (quantity) are inversely related, which is generally expected for most price/demand relationships. The same results were also found in profit average $\left(\varepsilon_{12}=-4.8\right.$ and $\left.\varepsilon_{21}=-22.0\right)$. The positive demand elasticity for an input in its own price implies that an increase in the price of an input would result in a higher demand.

Table 7.

Spearman rank correlation between economic efficiency and accounting profitability

\begin{tabular}{|c|c|c|c|c|}
\hline & $\mathrm{ROA}$ & $\mathrm{ROE}$ & Cost efficiency & Profit efficiency \\
\hline ROA & 1.000 & & & \\
\hline ROE & $0.547^{* * *}$ & 1.000 & & \\
\hline Cost efficiency & $-0.199^{* *}$ & $-0.076^{* *}$ & 1.000 & \\
\hline Profit efficiency & $-0.029^{*}$ & $-0.030^{* *}$ & $0.436^{* * *}$ & 1.000 \\
\hline
\end{tabular}

Note: ${ }^{* * *},{ }^{* *}$ and ${ }^{*}$ represent significance at $10 \%, 5 \%$ and $1 \%$, respectively.

Source: Authors' estimates from the data source.

Table 7 presents the Spearman rank correlation coefficients for the four variables (cost efficiency, profit efficiency, ROE and ROA). The first result shows that cost efficiency is negatively correlated with the ROA and the ROE. This correlation reveals that cost efficiency has little impact on the overall profitability of all the banks. In the same way, profit efficiency is negatively correlated with the ROA and the ROE; yet, it is positively correlated with cost efficiency.

\subsection{Comparison of accounting and economics-based profitability measures}

First, to make a comparison between the economics and accounting based results, we used the cost and profit efficiency measures from the preceding estimates. Second, to be able to understand the relationship between accounting and economics-based measures of profitability, it is necessary to add the cost and profit efficiency measures as independent variables in Eq. (11) 
for the estimation of the ROA and the ROE. Nevertheless, the results in Table 8 are not similar to those of Table 4 since they are based on time series averages that lead to a single average cross sectional data set of 110 observations. Only profit efficiency is a highly significant explanatory variable for both the ROA and the ROE.

The combination of profit efficiency, loan specialization ratio (LOANS), and the Choc dummy variable (CHOC) gives $5.9 \%, 0.7 \%$ and $2.1 \%$ of the variation in the ROA, respectively. However, the LOANS does not explain the variation in the ROE. These results again do not confirm that economics-based measures if profit efficiency is highly correlated with accounting-based measures of profitability.

A third approach to compare economics-based and accounting-based research, as already used in many previous studies (Hassan and Bashir, 2003; Fries and Taci, 2005; Bonin et al., 2005), is used to analyze the correlation between the two approaches. This includes second stage ordinary least square regressions where the individual bank cost and profit efficiency figures from Eq. (7), as shown in Table 5, are transformed into dependent variables and the introduced accounting variables as independent variables. As presented in Table 8, the LOANS and CHOC variables explain about $1.3 \%$ and $2.4 \%$ of the variation in cost efficiency. The profit efficiency variations are not explained by a single accounting variable but also by the inefficiency ratio (INEFF), which is defined as operating expenses divided by gross income. This explains about $2.2 \%$ of the variation in cost efficiency. These relationships indicate that cost and profit efficiency already capture much of the explanatory power of the accounting variables, although some accounting variables might still be useful in a better formulation of efficiency measures. Moreover, the variation of cost efficiency is explained by the variation of CRISK and CAPSTR.

Table 8.

Impact on efficiency and performance: Dynamic panel-data system GMM estimation

\begin{tabular}{|c|c|c|c|c|c|c|c|c|}
\hline \multirow[b]{2}{*}{ Independent variable } & \multicolumn{2}{|c|}{ Cost Efficiency } & \multicolumn{2}{|c|}{ Profit Efficiency } & \multicolumn{2}{|c|}{$\mathrm{ROA}$} & \multicolumn{2}{|c|}{ ROE } \\
\hline & one-step & two-step & one-step & two-step & one-step & two-step & one-step & two-step \\
\hline Cost efficiency $(-1)$ & $\begin{array}{c}0.692^{* * *} \\
(6.63)\end{array}$ & $\begin{array}{c}0.679^{* * *} \\
(4.86)\end{array}$ & - & - & - & - & - & - \\
\hline Profit efficiency $(-1)$ & - & - & $\begin{array}{c}0.255^{* *} \\
(1.98)\end{array}$ & $\begin{array}{l}0.221^{*} \\
(1.82)\end{array}$ & - & - & - & - \\
\hline ROA (-1) & - & - & - & - & $\begin{array}{c}0.686^{* * *} \\
(22.96)\end{array}$ & $\begin{array}{c}0.648^{* * *} \\
(5.65)\end{array}$ & - & - \\
\hline ROE (-1) & - & - & - & - & - & - & $\begin{array}{c}0.450^{* * *} \\
(12.77)\end{array}$ & $\begin{array}{c}0.593^{* * *} \\
(2.87)\end{array}$ \\
\hline Profit efficiency & - & - & - & - & $\begin{array}{c}0.059^{* *} \\
(2.26)\end{array}$ & $\begin{array}{l}0.034 \\
(1.38)\end{array}$ & $\begin{array}{l}2.62^{*} \\
(1.72)\end{array}$ & $\begin{array}{l}0.606 \\
(0.96)\end{array}$ \\
\hline LOANS & $\begin{array}{c}-0.013^{* *} \\
(-2.36)\end{array}$ & $\begin{array}{c}-0.008^{* *} \\
(-2.00)\end{array}$ & $\begin{array}{c}0.003^{* * *} \\
(5.67)\end{array}$ & $\begin{array}{c}0.003^{* *} \\
(2.01)\end{array}$ & $\begin{array}{c}-0.007^{* * *} \\
(-4.04)\end{array}$ & $\begin{array}{l}-0.004 \\
(-1.55)\end{array}$ & $\begin{array}{l}-0.135 \\
(-1.62)\end{array}$ & $\begin{array}{c}-0.21 \\
(-0.54)\end{array}$ \\
\hline INEFF & $\begin{array}{c}-0.022^{* *} \\
(-2.59)\end{array}$ & $\begin{array}{l}-0.018 \\
(-0.88)\end{array}$ & $\begin{array}{l}0.1 \mathrm{e}^{-3} \\
(0.03)\end{array}$ & $\begin{array}{l}0.8 \mathrm{e}^{-3} \\
(0.14)\end{array}$ & - & - & - & - \\
\hline CRISK & $\begin{array}{c}-0.022^{* *} \\
(-2.29)\end{array}$ & $\begin{array}{l}-0.019^{*} \\
(-1.89)\end{array}$ & - & - & - & - & - & - \\
\hline CAPSTR & $\begin{array}{l}0.030^{*} \\
(1.66)\end{array}$ & $\begin{array}{l}0.045^{*} \\
(1.67)\end{array}$ & - & - & - & - & - & - \\
\hline $\mathrm{CHOC}$ & $\begin{array}{c}0.024^{* *} \\
(2.54)\end{array}$ & $\begin{array}{c}0.017^{* *} \\
(2.26)\end{array}$ & $\begin{array}{c}-0.38 \mathrm{e}^{-3^{* *}} \\
(-2.11)\end{array}$ & $\begin{array}{l}-0.005 \\
(-1.36)\end{array}$ & $\begin{array}{c}0.021^{* * *} \\
(4.78)\end{array}$ & $\begin{array}{c}0.011^{* *} \\
(2.36)\end{array}$ & $\begin{array}{c}0.254^{* *} \\
(2.40)\end{array}$ & $\begin{array}{l}0.149^{*} \\
(1.91)\end{array}$ \\
\hline
\end{tabular}




\begin{tabular}{|c|c|c|c|c|c|c|c|c|}
\hline \multirow[b]{2}{*}{ Independent variable } & \multicolumn{2}{|c|}{ Cost Efficiency } & \multicolumn{2}{|c|}{ Profit Efficiency } & \multicolumn{2}{|c|}{ ROA } & \multicolumn{2}{|c|}{ ROE } \\
\hline & one-step & two-step & one-step & two-step & one-step & two-step & one-step & two-step \\
\hline Constant & $\begin{array}{c}0.405^{* * *} \\
(3.76)\end{array}$ & $\begin{array}{c}0.364^{* * *} \\
(2.88)\end{array}$ & $\begin{array}{c}0.689^{* * *} \\
(5.76)\end{array}$ & $\begin{array}{c}0.717^{* * *} \\
(6.22)\end{array}$ & $\begin{array}{l}0.033 \\
(0.96)\end{array}$ & $\begin{array}{l}0.019 \\
(0.56)\end{array}$ & $\begin{array}{l}-0.737 \\
(-1.06)\end{array}$ & $\begin{array}{l}-0.297 \\
(-0.42)\end{array}$ \\
\hline AR(1) correlation test & $-5.16^{* * *}$ & $-4.36^{* * *}$ & $-5.71^{* * *}$ & $-5.17^{* * *}$ & $-2.61^{* * *}$ & $-2.13^{* *}$ & -1.40 & -1.38 \\
\hline $\mathrm{AR}(2)$ correlation test & 0.23 & 2.63 & $2.36^{* *}$ & $2.20^{* *}$ & 0.33 & 0.64 & $5.48^{* * *}$ & 1.46 \\
\hline Sargan test & $9.11^{*}$ & $9.11^{*}$ & 2.26 & 2.26 & $71.01^{* * *}$ & $71.01^{* * *}$ & $114.8^{* * *}$ & $114.8^{* * *}$ \\
\hline
\end{tabular}

Note: ${ }^{* * *},{ }^{* *}$ and ${ }^{*}$ represent significance at $10 \%, 5 \%$ and $1 \%$, respectively.

Source: Authors' estimates from the data source.

While some accounting variables serve to describe both profitability ratios and efficiency, and even though the efficiency ranking and profitability ratios are a little correlated, the accountingbased and economics-based approaches to interpret the banking performance are not the same. They can present different rankings across banks or countries because the ROA and the ROE are measured purely per unit return on assets or equity. Cost and profit efficiencies are estimated on the basis of the principal practice bank and indicate a relative achievement of a potential profit. As shown in Table 5, the high values of profitability ratios are usually associated with high values of profit efficiency with a few exceptions. For example, Bahraini and Egyptian banks had a $2^{\text {nd }}$ and $3^{\text {rd }}$ rank in terms of the ROE and the ROA but $10^{\text {th }}$ and $11^{\text {th }}$ rank, only, in terms of profit efficiency. In general, the accounting-based and the economics-based approaches present the same measures of the relative banking performance, but they define different aspects of financial performance.

\section{CONCLUSION}

This paper analyzed the accounting-based determinants of profitability in some banks and compared these results with the economics-based determinants of cost and profit efficiency over the 1999/2012 period. From the accounting-based determinants of ROA and ROE, many variables related to profitability were outside the control of the bank management, like size, security, deposit and labor cost. Economics-based calculation of profit efficiency is closely related to the ROA and ROE accounting ratios. In general, our results show that the accounting-based and economicsbased approaches results of interpreting a bank performance are similar in some variables.

The empirical results of our study highlight that the positive correlation between the CHOC variable and the accounting profitability and profit efficiency revealed that the impact of the financial crisis on a bank's profitability is not relevant for the MENA countries banks, in particular, Malaysia, Saudi Arabia and Qatar that have the highest percentage of Average Efficiency.

Relying on the obtained results, we deduced that most conventional banks can improve their profitability, especially by raising the quality of the assets, developing the quality of the management, increasing the non-interest income and improving the bank size.

Therefore, the authorities are recommended to better supervise banks' credit and liquidity risk and enhance banking competition. Furthermore, banks' decision makers should control the liquidity risk indicators by diversifying the income resources and optimizing the costs.

To enrich future research, we had better deepen this analysis by expanding the study period and dividing our sample into groups of countries. In addition, we should take into consideration other explanatory variables for the banking profitability, such as interest rates, taxation, exchange rates or financial liberalization. 


\section{References}

Aigner, D., Lovell, C., and Schmidt, P., 1977. Formulation and estimation of stochastic frontier production function models. Journal of Econometrics, 6: 21-37.

Ahmed AS, Takeda C, Thomas S.E., 1998. Bank Loan Loss Provisions: A Reexamination of Capital Management, Earnings Management and Signaling Effects. SSRN pp: 1-39.

Albertazzi, U., and Gambacorta L., 2008. Bank profitability, the business cycle. Journal of Financial Stability, 5(4): 393-409.

Alper, D., and Anbar, A., 2011. Bank Specific and Macroeconomic Determinants of Commercial Bank Profitability: Empirical Evidence from Turkey. Business and Economics Research Journal, 2(2): 139-152.

Athanasoglou, P.P., Brissimis, S.N. and Delis, M.D., 2007. Bank specific, industry specific and macroeconomic determinants of bank profitability. Journal of International Financial Markets, Institutions and Money, 18(2): 121-136.

Barth, James R., Chen Lin b, Yue Ma, Jesús Seade and Frank M. Song, 2013. Do bank regulation, supervision and monitoring enhance or impede bank efficiency? Journal of Banking \& Finance, 37(8): 2879-2892.

Bauer, P., Berger, A., Ferrier, G., and Humphrey, D., 1998. Consistency conditions for regulated analysis of financial institutions: a comparison of frontier efficiency methods. Journal of Economics and Business, 50: 85-114.

Ben Naceur, S, and Omran M., 2008. The effects of bank regulations, competition and financial reforms on MENA banks' profitability. Working Paper, Economic Research Forum.

Ben Naceur, S., and Goaied, M., 2008. The determinants of commercial bank interest margin and profitability: evidence from Tunisia. Frontiers in Finance and Economics, 5: 106-130.

Ben Naceur, S., and Omran, M., 2011. The effects of bank regulations, competition, and financial reforms on banks' performance. Emerging Markets Review, 12: 1-20.

Berger, A., 1993. Distribution-free estimates of efficiency in the U.S. banking industry and tests of the standard distributional assumptions. Journal of Productivity Analysis, 4: 261-292.

Berger, A., and Mester, L., 1997. Inside the black box: what explains differences in the efficiency of financial institutions. Journal of Banking and Finance, 21: 895-947.

Bhuyan, R., and Williams, D. L., 2006. Operating performance of the US Commercial Banks after IPOs: An empirical evidence. Journal of Commercial Banking and Finance, 5(1/2): 68-95.

Bonin, J., Hasan, I., and Wachtel, P., 2005. Bank performance, efficiency and ownership in transition countries. Journal of Banking and Finance, 29: 31-53.

Chortareas, Georgios E., Claudia Girardone and Alexia Ventouri, 2013. Financial freedom and bank efficiency: Evidence from the European Union. Journal of Banking \& Finance, 37(4): 1223-1231.

De Young, R., and Rice, T., 2004. Non-interest income and financial performance at US Commercial Banks. Financial Review, 39(1): 101-127.

Deger, A., and Adem A., 2011. Bank Specific and Macroeconomic Determinants of Commercial Bank Profitability: Empirical Evidence from Turkey. Business and Economics Research Journal, 2: 139-152.

Dietrich, A., and Wanzenried, G., 2010. Determinants of Bank Profitability Before and During the Crisis: Evidence from Switzerland. Journal of International Financial Markets, Institutions and Money, 307-327.

Dietsch, M., and Lozano-Vivas, A., 2000. How the environment determines banking efficiency: a comparison between French and Spanish industries. Journal of Banking and Finance, 24: 985-1004.

Fries S., and Taci A., 2005. Cost efficiency of banks in transition: evidence from 289 banks in 15 post-communist countries. Journal of Banking and Finance, 29(1): 55-81.

Gaganis, Chrysovalantis and Fotios Pasiouras, 2013. Financial supervision regimes and bank efficiency: International evidence. Journal of Banking \& Finance, 37(12): 5463-5475.

Greene, W. H., 1997. Frontier production functions. In M. Hashem Pesaran, and P. Schmidt (Eds.), Handbook of applied econometrics: Microeconomics, Vol. II. Massachusetts: Black-well Publishers.

Hassan, K., and Bashir, A., 2003. Determinants of Islamic Banking Profitability. ERF paper, 10th Conference.

Hassan, M., 2005. The cost, profit and X-efficiency of Islamic banks. Paper presented at the Economic Research Forum 12th annual conference, Cairo, Egypt.

Hirtle, B. J., and Stiroh, K. J., 2007. The return to retail and the performance of US Banks. Journal of Banking and Finance, 31(4): 1101-1133.

Ho, M. T., and Tripe, D., 2002. Factors influencing the performance of foreign owned banks in New Zealand. Journal of International Financial Markets, Institutions and Money, 12(4/5): 341-357.

Hryckiewicz, A., and Kowalewski, O., 2010. Economic determinates, financial crisis and entry modes of foreign banks into emerging markets. Emerging Markets Review, 11: 205-228.

Jondrow, J., Lovell, C. A. K., Materov, I. S., and Schmidt, P., 1982. On the Estimation of Technical Inefficiency in the Stochastic Frontier Production Function Model. Journal of Econometrics, 19: 233-238.

Kosmidou, K., and Zopounidis, C., 2008. Measurement of bank performance in Greece. South Eastern Europe Journal of Economics, 6(1): 79-95. 
Kosmidou, K., Pasiouras, F., and Tsaklanganos, A., 2007. Domestic and multinational determinants of foreign bank profits: The Case of Greek Banks operating abroad. Journal of Multinational Financial Management, 17(1): 1-15.

Kumbirai, M., and Webb, R., 2010. A financial ratio analysis of commercial performance in South Africa. African Review of Economics and Finance, 2(1): 30-53.

Kwan, S., 2003. Operating performance of banks among Asian economies: an international and time series comparison. Journal of Banking and Finance, 27: 471-489.

Makkar A., and Singh S., 2013. Analysis of the Financial Performance of Indian Commercial Banks: A Comparative Study. Indian Journal of Finance, 7: 41-49.

Maudos J, Pastor J., and Pérez F., 2002. Cost and profit efficiency in European Banks. Journal International finance Markets Inst Money, 12(1): 33-58.

Maudos, J., Pastor, J.M., Perez, F., and Quesada, J., 2002. Cost and profit efficiency in European banks. Journal of International Financial Markets. Institutions and Money, 12: 483-497.

Muhammad, Raashid, Syed Aziz Rasool and Muhammad Usman Raja, 2015. Investigation of Profitability of Banking Sector: Empirical Evidence from Pakistan. Journal of Finance and Bank Management, 3(1): 139-155, June.

Nicolae, Petria, Bogdan Capraru and Iulian Ihnatov, 2015. Determinants of Banks' Profitability: Evidence from EU 27 Banking Systems. Procedia Economics and Finance, 20: 518-524.

Pasiouras, F., and Kosmidou, K., 2007. Factors influencing the profitability of domestic and foreign commercial banks in the European Union. Research in International Business and Finance, 21(2): 222-237.

Poghosyan, T., 2010. Re-examining the impact of foreign bank participation on interest margins in emerging markets. Emerging Markets Review, 11: 390-402.

Schmidt, P., and Lovell, C. A. K., 1979. Estimating Technical and Allocative Inefficiency Relative to Stochastic Production and Cost Frontiers. Journal of Econometrics, 9: 343-66.

Sealey, C., and Lindley, J., 1977. Inputs, outputs and a theory of production and cost of depository financial institutions. Journal of Finance, 32: 1251-1266.

Staikouras C., Mamatzakis E., and Koutsomanoli-Filippaki A., 2008. Cost efficiency of the banking industry in the South Eastern European region. Journal of International Financial Markets, Institutions and Money, 19: 483-497.

Stiroh, K. J., and Rumble, A., 2006. The dark side of diversification: The Case of US Financial Holding Companies. Journal of Banking and Finance, 30(8): 2131-2161.

Sufian, F., 2010. Financial Depression and the profitability of the banking sector of the Republic of Korea: Panel Evidence on bank specific and macroeconomic determinants. Asia-Pacific Development Journal, 17: 65-92.

Trujillo-Ponce, A., 2013. What Determines the Profitability of Banks? Evidence from Spain. Accounting and Finance, 53(2).

Valverde, S., and Fernandez, F., 2007. The determinants of bank margins in European banking. Journal of Banking and Finance, 31: 2043-2063.

Van Horen, N., 2007. Foreign banks in developing countries; origin matters. Emerging Markets Review, 8: 81-105.

Weill, L., 2004. Measuring cost efficiency in European banking: a comparison of frontier techniques. Journal of Productivity Analysis, 21: 133-152.

Weill, L., 2009. Convergence in banking efficiency across European countries. Journal of International Financial Markets, Institutions and Money, 19: 818-833.

Williams, B., 2003. Domestic and international determinants of bank profits: Foreign banks in Australia. Journal of Banking and Finance, 27(6): 1185-1210.

Yildirim, H.S., and Philippatos, G.C., 2007. Efficiency of banks: recent evidence from the transition economies of Europe, 1993-2000. European Journal of Finance, 13: 123-143.

Yilmaz, A.A., 2013. Profitability of Banking System: Evidence from Emerging Markets. WEI International Academic Conference Proceedings January 14-16, 2013, Antalya, Turkey.

Zellner, A., 1962. An efficient method of estimating seemingly unrelated regression equations and tests for aggregation bias. Journal of the American Statistical Association, 57: 348-368. 